\title{
Ajama-verbi polüseemia ja ajama-pöhjustamiskonstruktsioon eesti kirjakeeles
}

\author{
KAIRIT TOMSON
}

Ajama on üks eesti keele analüütilisse põhjustamiskonstruktsiooni kuuluvatest verbidest. Lisaks esineb panema- ja laskma-põhjustamiskonstruktsioon (Kasik 2001; Tomson 2018) ning tuumverbidest tähenduselt läbipaistvamate verbidega põhjustamist väljendavad konstruktsioonid, nagu meelitama $+m a$-infinitiiv. Põhjustamissituatsiooni väljendamiseks kasutatakse ka tuletusmorfoloogilisi (nt jooksu-ta-ma) ja leksikaalseid kausatiive (nt avama).

Artikli eesmärk on kirjeldada ajama-põhjustamiskonstruktsiooni kujunemist ja kasutust, sh üksikasjalikumalt sagedamini esinevaid konstruktsioonitüüpe XVIXXI sajandi eesti kirjakeele tekstide põhjal. Kõigepealt uuritakse kasutusnäidete tähendusi, et vastata kahele esimesele uurimisküsimusele: milliseid leksikaalseid tähendusi ajama-verb kannab ja millised on ajama-verbi sildkonstruktsioonid? Sildkonstruktsiooni igat rühma ühendab kindel vorm (nt ajama-verb + translatiiv) ja tähendus (nt pahaks ajama väljendab abstraktset seisundimuutust). Leksikaalsete kasutuste ja sildkonstruktsioonide kaudu on võimalik selgitada põhjustamistähenduse paiknemist polüseemilise ajama-verbi tähendusvõrgustikus. ma-infinitiiviga ajama-põhjustamiskonstruktsioone käsitletakse artiklis grammatiseerunud kasutusjuhtudena. Grammatiseerumine on leksikaalsest keeleüksusest grammatilise üksuse kujunemine (vt nt Heine jt 1991; Hopper, Traugott 1993). Nimetatud kahe uurimisküsimuse kõrval vaadeldakse ajama-põhjustamiskonstruktsiooni osaliste semantilisi rolle: näites 1 kuuluvad põhjustamiskonstruktsiooni ajama-verb, mainfinitiivis Tulemussündmus muigama, Mõjutaja see jutt (Jõud) ja Mõjutatav mind (KOGEJA). ${ }^{1}$

(1) Mind ajas see jutt natuke muigama. (delfi.ee) ${ }^{2}$

Ajama kuulub eesti keele tuumverbide hulka (Tragel 2003). Ajama-verbi keskseks tähenduseks võib pidada liigutamist, kuna see on kõige füüsilisem (nt olgu meile üks dokument, mida me hoolega läbi uurime ja seda edasi-tagasi kaaludes kui kallist pärli paela otsa ajame). Selle kõrval esineb palju sundimise tähendust (nt ema ajas tütre poodi leiva järele) (vt EKSS), mis omakorda kaasneb mõnel juhul põh-

\footnotetext{
${ }^{1}$ Semantilised rollid on artiklis tähistatud kapiteelkirjaga (AGENT, JõUd, KOGEJA, PATSIENT, TEEMA, SEISUND, TEGEVUS, SOORITUS, SAAVUTUS JA PROTSESS), konstruktsiooni komponendid eristuse mõttes ka esisuurtähega (Mõjutaja, Mõjutatav ja Tulemussündmus).

${ }^{2}$ Näited ja ülejäänud tekstis esinevad kasutusjuhud, millele pole eraldi viidatud, pärinevad korpusmaterjalist. Näidete kirjapilt on esitatud muutmata kujul.
} 
justamiskonstruktsiooni tähendusega. Eesti keele ajama-verbi leksikaalset (võrdluses soome keelega) ja grammatilist kasutust on varem käsitlenud Reet Kasik (1999, 2001). Liina Lindström (2012) nimetab ajama-põhjustamiskonstruktsiooni tundekausatiivikonstruktsioonide seas. Eesti keele analüütilisi põhjustamiskonstruktsioone on käsitletud ka balti keelte kontekstis: võrreldud on eesti verbide panema, andma, laskma ja sundima kausatiivse kasutuse kujunemist kõrvutatuna läti ja leedu keeles toimuvate tähendusmuutustega (Pakerys 2017; teistes keeltes vt nt Stefanowitsch 2001; Nolan jt 2015).

Artikli esimeses osas antakse ülevaade ajama-verbi tähendustest sõnaraamatute põhjal. Teises osas tutvustatakse uurimuse materjali ja metoodikat. Kolmandas osas esitatakse ajama-verbi korpusmaterjali põhjal moodustatud leksikaalsed tähendusrühmad ja nende kirjeldus. Neljandas osas käsitletakse ajama-verbi sildkonstruktsioone, mis kuuluvad grammatiseerumisprotsessis nii tähenduslikult kui ka vormiliselt leksikaalsete ja grammatiliste kasutuste vahealasse. Viiendas osas keskendutakse ajama-verbi grammatilisele põhjustamiskonstruktsioonile, esitades selle erinevad tüübid konstruktsiooni osaliste semantiliste rollide kaudu. Kuuendas osas tuuakse välja leksikaalsete tähenduste, sildkonstruktsioonide ja grammatilise kasutuse seosed ning viimases osas võetakse tulemused kokku.

\section{Ajama-verbi sõnaraamatutähenduste ülevaade}

Ajama-verbi vasted eesti keele sugulaskeeltes osutavad mitmel juhul (hobusega) sõitmisele, tagaajamisele ja sundimisele. Vasted on nt liivi a’ijjõ, vadja ajaa, soome ajaa, vepsa ajada, saami vuodjit ja komi vojni. (EES 2012: 48) Ajama-verbi rekonstrueeritud algtüvi on *aja- (Häkkinen 2005: 37).

Wiedemanni eesti-saksa sõnaraamatus (1923 [1869]) on ajama-verbi tähendused jagatud seitsmesse rühma. Esimeses tähendusväljas on nimetatud fortbewegen 'kohalt liigutama, edasi viima', treiben 'sundima, ergutama, käima panema, tegelema', (betreiben 'tegelema, harrastama, pidama, käitama', antreiben 'tagant sundima, virgutama, ergutama', anregen 'algatama, ajendama, virgutama', fahren 'sõitma, kargama,' jagen 'jälitama, (välja) kihutama'), mis võivad seostuda erinevate asjaoludega (nt kaupa ajama, lindu ajama, nalja ajama, elu ajama, süüd teise peale ajama, vagusid ajama, oksele ajama, viina ajama, juttu ajama ja aetud hobune). Teise rühma moodustavad tähendused nachgehen 'järgnema', verfolgen 'taga ajama', fordern 'nõudma' ja eintreiben '(karja) lauta ajama' (kasutusnäited jälgi ajama, õigust ajama ja peale ajama). Kolmas tähendusrühm väljendab häälitsemist ja muusikainstrumendil mängimist (nt need linnud ajavad „sor sor" ja kannelt ajama). Neljas rühm koondab tähendused vertreiben 'minema kihutama', abtreiben '(ära) ajama', abschneiden 'eraldama', abscheren 'maha pügama' ja abfressen '(ära) sööma' (nt habet ajama, karva ajama ja koi ajanud riideid ära). Viiendasse rühma kuuluvad tähendused nähen 'õmblema' ja sticken 'tikkima' (nt üle ääre ajama 'üle ääre ómblema'). Kuuenda rühma tähendused väljendavad mingisse seisundisse viimist (nt kuumaks ajama, 
ennast sirgeks ajama ja täide ajama). Ajama-verb on siin enamasti koos faktiiviga ${ }^{3}$, aga ka allatiivi ja illatiiviga. Seitsmendas rühmas on tähendused sich wohin begeben 'end kuhugi käima ajama', in einen Ort oder Zustand übergehen 'paika või seisundisse (üle) minema', werden 'muutuma' (nt himudest ajama, vili ajab oraksele ja pilvesse ajama). (Wiedemann 1923 [1869]: 15-18) Wiedemanni sõnaraamatus esitatud kasutuste hulgas ma-infinitiiviga ajama-põhjustamiskonstruktsiooni ei ole. Nimetatud on aga palju näiteid mitmesugustesse seisunditesse viimisest. Kuuendas tähendusrühmas toob Wiedemann välja sinna kuuluvate kasutusjuhtude vormilise ühtsuse, st täpsustab, mis käändes sõnadega ajama-verb koos esineb.

Andrus Saareste mõistelises sõnaraamatus on ajama-verbi kasutused esitatud sellistes mõisterühmades nagu eemaldama, lükkama, sundima, laulma (nt viisi üles ajama), lugema (nt läbi ajama), nõudma (nt tema ajab seda õigust) ja korraldama (nt läks oma asju ajama). Näiteid leidub ka kitsamate mõistete all, nagu näiteks noot (täna minnakse noota ajama). (Saareste 1958-1963)

Tänapäeva eesti keelt kajastavas seletavas sõnaraamatus (EKSS) on ajama-verbile antud 16 põhitähendust. Laiematest tähendusrühmadest on esimesena nimetatud teatud suunas või kuhugi liikuma sundimist; (kuhugi) midagi tegema sundimist; tagant kihutamist ja kannustamist. See, nagu ka mõni teine ajama-verbi tähendusrühm, on jagatud omakorda alltähendusteks. Teistest põhitähendustest on EKSS-is nimetatud '2. end, oma keha või mõnd kehaosa teatud suunas, kuhugipoole liigutama, teatud asendisse viima jne' (nt lind ajas noka lahti), '3. mingit füsioloogilist protsessi või psüühilist seisundit, tundmust, meeleolu jne esile kutsuma' (nt see ajab lausa vihaseks, väsimus ajab haigutama) ja '4. midagi või kedagi mingisugusesse olukorda, seisundisse viima või mingisuguseks muutma' (nt tuul ajab juuksed sassi, vesi aeti keema). Ülejäänud tähendusrühmad on EKSS-is spetsiifilisemad, nagu nt '16. habet, juukseid raseerides või masinaga lõigates eemaldama’.

\section{Materjal ja meetod}

Materjal ajama-verbi kasutuse uurimiseks on kogutud Tartu Ülikooli vana kirjakeele korpusest, eesti kirjakeele korpusest, veebilehtede korpusest etTenTen ja Sketch Engine'i päringuga eesti keele ühendkorpusest 2017. Vana kirjakeele korpuse XVI sajandi põhjaeesti tekstides ajama-verbi kasutusi ei leidu. XVII sajandi materjalist on ajama-verbi otsing tehtud järgmistest põhjaeesti tekstidest: Georg Mülleri jutlused (1600-1606), Joachim Rossihniuse „Evangelia und Episteln” (1632), Heinrich Stahli „Hand- und Hausbuch” III ja IV osa (1638) ja „Leyen Spiegel” II osa (1649). XVIII sajandi otsingusse kaasati Uus Testament (1715), Anton Thor Helle „Kurtzgefaßte Anweisung Zur Ehstnischen Sprache” 10 dialoogi (1732), „Wiis head jutto” (1740), August Wilhelm Hupeli „Lühhike öppetus” (1766-1767), Johann Lithanderi „Köki ja Kokka Ramat” (1781), Friedrich Wilhelm Willmanni „Juttud ja Teggud” (1782), Friedrich Gustav Arweliuse „Üks Kaunis Jutto ja Öppetusse Ramat” (1782) ja

${ }^{3}$ Faktiivi (= translatiiv) kohta vt Wiedemann 1875: 335-338 ja Ernits 2008. 
Nicolaus von Hagemeisteri „Lühhikenne öppetus maa-rahwale” (1790). XIX sajandi ajama-verbi kasutusnäidete otsing tehti kõikidest vana kirjakeele korpuses olevatest trükitekstidest ning eesti kirjakeele 1890. aastate korpusest. XX sajandi materjal pärineb eesti kirjakeele korpusest. XXI sajandi etTenTeni otsingule seati piirang, et liiga suur osa valimist ei pärineks samast allikast: ühelt veebiaadressilt võeti kuni kümne otsinguvaste korral valimisse kõik laused, enamatest esinemisjuhtudest mitte rohkem kui 15 lauset.

Nimetatud allikates esines 2366 ajama-verbi kasutusjuhtu lihtverbina, ühend- või väljendverbis, fraseologismis, sildkonstruktsioonis (ei ole infinitiivikonstruktsioon, kuid väljendab mingi seisundi põhjustamist, nt segadusse ajama) või grammatilises konstruktsioonis (tabel 1).

Tabel 1. Ajama-verbi tähendusrühmade moodustamiseks analüüsitud materjali hulk.

\begin{tabular}{|l|c|c|c|c|c|c|}
\hline Periood & $\begin{array}{c}\text { XVII } \\
\text { sajand }\end{array}$ & $\begin{array}{c}\text { XVIII } \\
\text { sajand }\end{array}$ & $\begin{array}{c}\text { XIX } \\
\text { sajand }\end{array}$ & $\begin{array}{c}\text { XX } \\
\text { sajand }\end{array}$ & $\begin{array}{c}\text { XXI } \\
\text { sajand }\end{array}$ & Kokku \\
\hline Analüüsitud kasutusjuhtude arv & 134 & 199 & 697 & 831 & 505 & 2366 \\
\hline
\end{tabular}

Materjaliga tegeleti kahes osas. Esiteks moodustati ajama-verbi võimalikult laiad tähendusrühmad (vt ptk 3-5), vajaduse korral koos allrühmadega. Iga tähendusrühma juures tuuakse näiteid sinna kuuluvatest ühenditest. Sama ühend võib olenevalt kontekstist kuuluda erinevatesse tähendusrühmadesse. Siinses uurimuses kasutatud tähendusjaotus erineb EKSS-ist peamiselt selle poolest, et kattub ka konstruktsiooni osaliste vorm, st EKSS-i liigituses on samasse tähendusrühma paigutatud siinse analüüsi seisukohalt leksikaalsete, sildkonstruktsioonide ja grammatilise rühma ühendeid. Tähenduse ja vormi kokkukuuluvus kui konstruktsioonigrammatika oluline põhimõte (vt nt Goldberg 1995) tuleb hästi esile näiteks mingisse seisundisse viimise tähenduses kasutatud sildkonstruktsioonides, mis on väljendatud kindla vormiga, nt ajama-verbi ja translatiivis noomeni koosesinemisega (nt keeruliseks ajama). Sama vorm võib kasutusel olla eri tähendusrühmades, nt vrd ekstsentrikust aetud ja uudishimust aetud. Need ühendid erinevad tähenduslikult, kuid neid seob vormiliselt elatiiviga väljendatud tegevuse põhjus. Ajama-verbi tähendust aitavad neis fraasides määrata sõnad ekstsentrikust ja uudishimust. Verbitähenduse üle aitavadki sageli otsustada samas lauses olevad teised elemendid (Tragel, Taremaa 2019: 212). Tähendusrühmade sagedused sajandite lõikes on kokkuvõtlikult esitatud 6. peatüki tabelis 3 .

Teiseks eraldati materjalist grammatilise ajama-põhjustamiskonstruktsiooniga laused (123, millest 62 väljendavad kõiki osalisi eksplitsiitselt ja 61 on eksplitseerimata osalis(t)ega). Neile lisati ühendkorpusest (vaadatud Sketch Engine'i kaudu) 1341 ajama-põhjustamiskonstruktsiooni, neist 396 väljendavad kõiki osalisi eksplitsiitselt. Kokku analüüsiti 1464 grammatilist kasutusjuhtu. Analüütilise ajamapõhjustamiskonstruktsiooni skeem:

Mõjutaja (nominatiiv) + ajama-verb + Mõjutatav (genitiiv, partitiiv) + TulemussüNDMuse verb ( $m a$-infinitiiv) 
Kõiki osalisi eksplitsiitselt väljendavatest lausetest (kokku 458) moodustati nendes esinevate semantiliste rollide põhjal konstruktsioonitüübid, nt lauses Toitumisspetsialiste ajavad need teooriad mõnikord naerma on MõjuTAJA need teooriad ja Mõjutatav toitumisspetsialistid (vt ptk 5). Eksplitseerimata osalisega kasutusjuhte (nt Lõpuks ajas küll juba öökima, puudub Mõjutaja ja Mõjutatav) kirjeldatakse lähemalt peatükis 5.1 .

Järgnev käsitlus esitab ajama-verbi tähenduste seoste kirjelduse, selgitades selle kaudu grammatilise ajama-põhjustamiskonstruktsiooni kujunemist.

\section{Ajama-verbi leksikaalsed tähendused}

Ajama-verbi leksikaalsed tähendused jaotati siinses uurimuses nelja rühma: 1) 'liigutama, lükkama', 2) 'sundima, suunama', 3) 'millegagi püsivalt tegelema või iseeneslikult püsivalt toimuma', 4) 'liikuma'. Liigutamise-lükkamise ja millegagi püsivalt tegelemise rühmas tehtud kasutusjuhtude alajaotused eristavad (kellestki/millestki) mõjutatud tegevust ja enesekohast või iseeneslikku tegevust.

1) Liigutamise ja lükkamise tähendusega kasutusjuhtudes kontrollib Mõjutaja olukorda sündmuse lõpuni, olles ise seal juures. See tähendab füüsilist tegevust väljendavatel juhtudel, et Mõjutaja hoiab füüsiliselt MõjuTATAvast kinni ja liigutab või lükkab seda mingis suunas või mingisse kohta. MõJutatav ei saa vastupanu osutada. Sellistele tingimustele vastavaid kasutusjuhte on materjalis aga vaid üksikuid (näide 2 ).

(2) Selleks tehti jäässe rida auke ja aeti püünis nende kaudu pika lati ning nööride abil vette [---]. (www.erm.ee)

Osa selle tähendusrühma näidetest on tunderõhulised ja argikeelsed, nt selga ajama, sõstraid suhu ajama, ennast välja ajama. Näiteks ühendis selga ajama võiks ühendi neutraalse tähenduse saamiseks asendada ajama-verbi tegusõnaga panema, st selga panema. Tunderõhulise ehk emfaatilise kasutuse näitena saab tuua ka ühendi selga toppima.

Osa korpusmaterjali näiteid ilmestab juhtumeid, kus keegi liigutab mingit objekti, v.a iseennast. Nende kasutuste hulgas esineb ajama-verb lihtverbina (näide 2) või verbiühendites, nt eemale ajama, maha ajama, edasi ajama, sisse ajama, läbi ajama, külge ajama ja ülle ajama. Näites 3 on eemale aetavaks objektiks liiv.

(3) Hakkasin ühe jämeda tüve ümbert liiva eemale ajama. (www.matkaklubi.ee)

Enesekohastel kasutusjuhtudel liigutatakse kuhugi või mingisse asendisse iseennast, nt (end) küünarnukile ajama, sirgu ajama, püsti ajama. Näites 4 liigutab subjekt ennast, st muudab oma istuva asendi püstiseks.

(4) Kaarel keeras raadio kinni ja ajas enda kivilt püsti. (ILU 1990) 
MõjutajA on mõnel juhul ka loodusjõud - enamasti tuul (näide 5).

(5) Lehe arwates on need sündinud mõnesugustest lõhkeainetega täidetud asjust, mis tuul merelt randa ajanud. (AJA 1910)

Ehkki tähendusnüanssides pisut varieeruv, on liigutamise ja lükkamise tähendusrühm üheselt määratletav ka selle poolest, et MõjutajA on tegevusega, mille ta/see tekitab, lähedalt seotud. Näiteks kui autot aetakse välja, siis ollakse tegevuse jooksul seal juures. Liigutamise ja lükkamise tähenduses näidete osakaal kõikidest ajama-verbi kasutusjuhtudest on väike - tänapäeva keeles umbes $6 \%$.

2) Sundimise ja suunamise tähendusrühma iseloomustab see, et AGENT mõjutab elusolendit, kes saaks ka vastupanu osutada. Sundimise ja suunamise tähenduses esineb ajama-verb lihtverbina (näide 6) või ühendites, nt ära ajama, minema ajama 'ära ajama’, välja ajama (näide 7).

(6) Ajas terve pere ilusti esiritta, lootes vanu tuttavaid lasteraamatust kohata.

(www.virufolk.ee)

(7) Kui välja ajab, tule minu poole. (ILU 1990)

Lisaks esineb sundimise tähenduses ka kujundlikke kasutusi, nt peale ajama 'peale käima' (näited 8-10), mis pealekäimise tähenduses on omaette ühend juba XVII sajandi tekstides (näited 8 ja 9). Ühend peale ajama on kasutusel ka tänapäeva keeles. Näites 10 viitab teise jaoks ebahuvitava pika jutu vestmine ja selle tegevuse jätkamine sellele, et ühendil peale ajama on tüütamise tähendusvarjund.

(8) Olcket röhmsat lohtusse siddes / kannatalickut willitzusse siddes / hajaket pehle palwede kahs. (Stahl 1638)

(9) Agga nemmad ajasid sure Kissendamissega päle / ja pallusid tedda Risti lüa / ja nende ja üllema-Preestride Hääl wottis Woimust. (UT 1715)

(10) Näiteks: „Moraal on see, kui ta ajab reegleid taga ja sulle seda, mis sind ei huvita, aga tema ajab ikka peale; ajab pikka juttu kogu aja ja ei jäta järele”. (www.eelk.ee)

Enamasti esineb ajama-verb sundimise tähenduses koos kohaargumendiga, st osutatakse кOHALE, kuhu kedagi sunnitakse (näites 7 välja). Kohaargumendi olemasolu võib, kuid ei pruugi osutada sellele, et ajama-verbil on sellises kasutuses sundimistähendus. Vana kirjakeele näited 11 ja 12 ilmestavad seda, kuidas ajamaverbi saab sundimise tähenduses kasutada ka kohaargumenti lisamata. Sundimistähendus järeldub neis näidetes kontekstist. Ilma kohaargumendita saab ajama-verb esineda ka sellise tähendusega lausetes, kus loomi sunnitakse edasi minema (näide 13). Loomi käsitletakse nagu inimesi - mõlemad saavad vastupanu osutada.

(11) [---] Wennad! mis peame meie ennam ellama, sest meie peame wägga paljo kannatama, et keik meite peäle kippuwad; keik meid aiawad; nink keikide eest peame ennast kartma. (1715, Willmann) 
(12) [---] ô ylus oinas, ytle pallomö, kes sina ay, et sina meye pattut henne olal kanat? (1587, Boierus)

(13) Karjad mida aeti olid 200-500 pealised [---]. (maainfo.ee)

Sundimise tähenduses ajama-verb esineb ka põhjuslikku suhet väljendavas otstarbelauses (vt Erelt, Metslang 2017: 723-727). Sellistes ajama-verbi kasutustes puudub samuti kohaargument, kuid esildub et-kõrvallausega väljendatud pealause sündmuse otstarve, st kedagi sunnitakse mingi tegevuse alustamise eesmärgil. Näites 14 esineb ajama otstarbelause lihtverbina ning on käsitlusse kaasatud näitamaks, kuidas et-kõrvallause aitab verbi tähendust määrata.

(14) Ning seddamaid ajas Jesus ommad Jüngrid, et nemmad piddid Laewa astuma [---]. (1715, UT)

Sageduselt on sundimise ja suunamise tähendusrühm olnud alates XIX sajandist liigutamise ja lükkamise tähendusrühmaga umbes sama osakaaluga ja sarnane on ka muutus nende kasutusjuhtude vähenemise suunas. Analüüsitud XVI-XVIII sajandi materjalis leidub sundimise ja suunamise tähenduses näiteid tunduvalt rohkem kui liigutamise ja lükkamise tähenduses näiteid (vt ptk 6 tabel 3).

Sundimise alaliigina võib käsitleda kannustamise tähendust, mille puhul on sundija JõuD, mitte inimene. JõuD on elutu ega põhjusta mingit seisundit, vaid kedagi sunnitakse minema mingisse kohta. Näites 15 on Jõu rollis abstraktne uudishimu. Harvadel juhtudel võib конт olla ka eksplitseerimata.

(15) Ärkame 7 ajal ja uudishimu, mis paista laevalt silmapiiri taha ajab mind ülemisele tekile. (www.getaway.ee)

Siia rühma sobituvad ka konstruktsiooni elatiiv + ajama (enamasti passiivina aetud) näited, mille kasutus on sagedam vanemates tekstides, nagu näidetes 16 ja 17. Näide 18 pärineb XX sajandi esimesest poolest. PõHJUsTAJA on elatiivi käändes subjekt.

(16) üx igkalick sahp kiusatut / kus temma ommast hennessest himmust hajatu [---] (Stahl, 1638)

(17) Agga kui teid Waimust aetakse / siis ei olle teie mitte Kässu al (UT 1715)

(18) Läbisõidutee ääri palistas imestusest ja uudishimust aetud saare walge- mustaja kollanahkne elanikkond. (AJA 1930)

Seega võib sundimist käsitleda kui agentiivse MõjutAJAGA protsessi, aga nagu materjalist selgub, siis võib selle kõrval kannustada ka Jõud. Ühendis minema ajama 'ära ajama', mis väljendab tegevuse lõpetatust, on näha, et sama verbiühend võib esineda nii koos AGENDi (näide 19) kui ka Jõu rollis MõjutaJAGA (näide 20).

(19) Siis saabus kuningas ja ajas sõjaväelased minema. (AJA 1990) 
(20) Ahastus ja stress ajasid mu teenistusest peaaegu minema. (www.harta.ee)

3) Millegagi püsivalt tegelemise tähenduses esineb ajama-verb kõige sagedamini. XVIII, XX ja XXI sajandil on selle tähenduse osakaal suurim, ulatudes isegi üle $40 \%$. Suurem osa sellesse tähendusrühma kuuluvatest ajama-verbi ühenditest väljendab tahtlikku tegevust, kuid nende kõrval väljendavad mõned ühendid ka millegi iseeneslikku toimumist. Tähendusrühma ühendab tegevuse püsivus ja ühendid esinevad enamasti vormis substantiiv partitiivis + ajama.

Millegagi tahtlikult püsivalt tegelemise hulgas saab eristada kitsamaid tähendusgruppe. Üks osa neist kasutustest osutab mingi alaga tegelemisele, nt äri ajama, poliitikat ajama, advokatuuri ajama. Tegevus võib olla ka mingile kindlamale eesmärgile suunatud, nt pabereid ajama, luba ajama, käsku ajama. Üks sagedamatest tahtliku tegutsemise tähenduses ühenditest on nimetatud näidetest üldisema sisuga asja/asju ajama (näide 21).

(21) Kõiki maisemaid asju aetakse neil teiste kalendrite järgi. (www.alkeemia.ee)

Tahtliku püsitegevuse tähenduses on kasutusel ka ühendid, mis annavad edasi midagi häälega väljendatavat, nt juttu ajama, jorinat ajama, naeru ajama. Neist kõige sagedamini esineb ühend juttu ajama (näide 22). Nimetatud näidetega sarnased (kõnelemisega seotud) on ka nt häma ajama, jama ajama, loba ajama, nalja ajama. Sellised ühendid väljendavad enamasti ebausutavat mõtet. Osa selle rühma ühenditest kujutab mingi käitumisjoone järgimist, nt jonni ajama ja kiusu ajama.

(22) Mina ajasin perenaisega juttu Tartu rahvast. (www.erm.ee)

Osa protsesse toimub iseeneslikult. Näiteks kui loomad ajavad karva (näide 23), siis ei tee nad seda tahtlikult. Iseeneslikud protsessid saavad olla seotud ka taimedega, nt juuri ajama, võsusid ajama, või asjaga, nt (suitsu) sisse ajama, vahtu ajama.

(23) Tubastes tingimustes peetavad loomad ei vaheta karva küll üldiselt nii kategooriliselt, kuid nad ajavad vähemal määral karva aastaringselt. (www.husky.ee)

4) Li ikumistähenduses ajama-verb osutab enamikul kasutusjuhtudest liikumisele sõiduvahendiga, nt hobuse või mõne sõidukiga, kuid võib osutada ka kõndimisele. Mõnest üksikust kasutusjuhust ei selgu, millega või kuidas liigutakse. Näites 24 on väljendatud poisi liikumist mingi sõiduvahendiga, näites 25 aga inimeste kõndimist läbi lume.

(24) Et poiss on pöörane kihutaja, ajab veel vastu posti või niisama kraavi [---]. (ILU 1970)

(25) Halle ja põllastamise wäert olli se nähha, kuida innimeste hulgad ni waewalisel wisil läbbi lumme laggedate peäle ajasid [---]. (Suve Jaan 1841) 
Peale nende kasutusjuhtude esineb ka püsiühendeid, nagu nt mööda ajama, järgi ajama, ratsa ajama, ringi ajama ja alla ajama. Korpuses etTenTen esinesid näited järgi ajama ja alla ajama. Eesti keeles on ajama-verb liikumistähenduses enamasti mingi varjundiga, osutades sageli näiteks kiirele sõidule (eriti hobusega). Sellist neutraalset juhtimise/sõitmise/reisimise tähendust nagu ajaa-verbil soome keeles, nt he ajoivat satamasta hotelliin 'nad sõitsid sadamast hotelli' (ESS), analüüsitud kirjakeele materjalis ei leidunud. ${ }^{4}$ Liikumistähenduse osakaal ajama-verbi kasutusjuhtudest on enamikul siinses uurimuses vaadeldud ajajärkudest üks-kaks protsenti. Mõnevõrra rohkem, 5\% kasutusjuhtudest, esines seda XIX sajandi tekstides - need on enamasti seotud hobusega sõitmisega.

\section{Sildkonstruktsioon 'mingisse seisundisse viima'}

Sildkonstruktsioonideks on arvatud sellised ajama-verbi kasutusjuhud, mis väljendavad mingi seisundi põhjustamist, kuid ei ole vormiliselt infinitiivikonstruktsioonid. Põhjustatakse mitmesuguseid seisundeid, mille võib jagada füüsilisteks (st meeleliselt tajutavad) ja abstraktseteks (st meeleliselt tajumatud). Abstraktsete seisundite hulgas on näiteks emotsionaalsed ja tegevuslikud seisundid. Mõned ühendid võivad olenevalt lause muudest semantilistest osalistest väljendada mõlemat, nii füüsilist kui ka abstraktset seisundit. Näiteks võib suureks ajada silmi või osavõtjate arvu, viimane väljendab kujundlikku mõistet.

Sildkonstruktsioonid jagunevad viide rühma, mida ühendab peamiselt vormitunnus, aga ka tähendus, ehkki välistatud ei ole mõnda teise tähendusrühma kuulumine.

1) ajama + translatiivis noomen väljendab mingisse füüsilisse seisundisse viimist seisundimuutuse tähenduses, nt sirgeks ajama, pikaks ajama, puruks ajama, teravaks ajama (näites 26 on väljendatud füüsilist seisundit terav); samuti abstraktsesse seisundisse viimist, nt ühendites keeruliseks ajama, segaseks ajama, (südant) pahaks ajama (näide 27), hulluks ajama.

(26) Ajage uisud teravaks. (www.aloha.ee)

(27) Ravimitel on siiski tõsised kõrvalmõjud - nad ajavad südame pahaks [---]. (www.paikesetoit.ee)

2) ajama + illatiivi sildkonstruktsioonis esineb illatiivilähteline seisundivorm, nt uppi ajama, kikki ajama, krussi ajama, vahtu ajama. Nende algvorm võib olla läbipaistvam, nagu ühendis vahtu ajama (nominatiivis vaht), või läbipaistmatum, nagu näites 28 uppi. Abstraktsesse seisundisse viimine väljendub nt ühendites joonde ajama, pankrotti ajama, segadusse ajama, paanikasse ajama, tülli ajama, pöördesse ajama. Abstraktne seisund hõlmab muuhulgas emotsionaalseid seisundeid, nagu segadusse ajama näites 29.

\footnotetext{
${ }^{4}$ Ajama-verbi kasutatakse sõitmistähenduses Kuusalu murrakus (RKS).
} 
(28) Paar korda aetakse ämber uppi. (ILU 1990)

(29) [---] ja Meinardile tundus see lugu väga kahtlane, sest nii vanad mehed tavaliselt tikku ei küsi aga ta ei lasknud ennast sellest segadusse ajada [---]. (ILU 1990)

3) ajama + allati ivis n o o m e n saab samuti väljendada füüsilisse seisundisse viimist, nt nähtavale ajama, pikale ajama (näide 30), aga ka mitmesuguseid emotsionaalseid seisundeid, nt vihale ajama, ärevile ajama, meeleheitele ajama. Selles rühmas on ka tegevuslikke seisundeid, nt tööle ajama, vargile ajama ja liikvele ajama, mis on lähedal ma-infinitiiviga põhjustamiskonstruktsioonidele (vt ptk 5) ja mida saab seostada ka sundimise tähendusega.

(30) Paan ajas näpu pikale ja tsuskas lõbuitsitust tagasi hoides kordamööda nii Voldemari kui ka Augustit. (ILU 1970)

(31) [---] torm oli Eeslahes jää liikwele ajanud ja see triiwis nüüd randa. (AJA 1930)

4) Verbiüh endid esinevad füüsilisse seisundisse viimise tähenduses, nagu lahti ajama ja kinni ajama (näide 32), mis väljendavad ühtlasi seisundi põhjustamist. Nendes ühendites käändevorm enam läbi ei paista. Abstraktsesse seisundisse viimist väljendavad nt verbiühendid (und) ära ajama ja üles ajama 'äratama' (näide 33).

(32) Euroopas on selliseid kraave juba pikemat aega kinni aetud.

(www.eestiloodus.ee)

(33) Nüüd saad valmistada hommikuti tervislikku hommikueinet, ajamata oma armsaid unimütse üles. (www.delimano.ee)

5) Vormiliselt varieeruvad kasutusjuhud, millest suurem osa on fraseologismid, nt asja põranda alla ajama, nalja liiga kaugele ajama, hirmu peale ajama ja vihkamist südamesse ajama.

\section{Ajama-verbi grammatiline põhjustamiskonstruktsioon}

Grammatilise tähendusena käsitletakse öeldisverbi vormis avalduvat sündmusülest tähendust (Erelt, Metslang 2017: 108). Ajama-konstruktsiooni ainus grammatiline tähendus on põhjustamistähendus, mis avaldub infinitiiviga tarindis. Siinse materjali põhjal leidusid esimesed ajama-põhjustamiskonstruktsiooni kasutuse näited Otto Reinhold von Holtzi tekstis „Luggemissed Eestima Tallorahwa moistusse ja südame juhatamiseks" (1817), nt

(34) Kül süddame tiggedus aiab mitto innimest ka sellele kurja teggema, kes temmale head teeb ja unnustab omma wihha toius keik armo ärra mis ta on sanud.

Ajama-põhjustamiskonstruktsioon on esitatud ka XIX sajandi grammatikates: Ahrensi grammatikas (1853: 108-109) on näited ma ajan teda jooksma ja aja pois 
seie, niitma. Wiedemanni grammatikas (1875: 446) on ajama-verbi (sks treiben) nimetatud koos teiste objekti nõudvate verbidega, mis esinevad koos ma-tegevusnimega (verbaalnoomeniga). Teised sarnased verbid on näiteks panema, sundima, kihutama ja viima.

Siinse analüüsi tarbeks on kogutud 458 ajama-põhjustamiskonstruktsiooni kasutusjuhtu alates esimestest esinemisest XIX sajandi alguses kuni tänapäevani ning moodustatud nende põhjal ajama-põhjustamiskonstruktsiooni tüübid (vt meetodi kohta ptk 2). Selline analüüs võimaldab kirjeldada ajama-põhjustamiskonstruktsiooni semantikat ning võrrelda seda panema-põhjustamiskonstruktsiooni semantikaga (vt Tomson 2016, 2018). Põhjustamiskonstruktsiooni osaliste semantilised rollid avavad seda, millisest leksikaalsest kasutusest võib tarindi kujunemine motiveeritud olla, kuna leksikaalsed kasutused on määratletud kindlate semantiliste rollidega (mida panema- ega ajama-verbi uurimuses pole süsteemselt märgendatud, kuid mis avalduvad rühmaülesena, nt seostub liigutamise tähendus agentiivse MõjUtajAGA). Seega pakub semantiline analüüs võimaluse avada eesti keele põhjustamiskonstruktsioonide kujunemisteede sarnasusi ja erinevusi.

Järgnevalt esitatud konstruktsioonitüüpide moodustamiseks on 458 kasutusjuhul määratud semantilised rollid: Mõjutaja (aGent või jõud), Mõjutatav (Patsient, KOGEJA või TEema) ja ma-infinitiiviga väljendatud Tulemussündmus (TEgevus, PROTSESS, SEISUND, SAAVUTUS või SOORITUS). Verbide liigitamiskriteeriumid põhinevad peamiselt Zeno Vendleri (1957) situatsioonitüüpide kirjeldusel, ent mõne verbi(rühma) semantilise rolli määratlemisel on toetutud ka teistele käsitlustele (nt Kasik 2015).

Kuna TulEmussüNDMUSE verbide hulk on suur ja mitmekesine, on lõplik verbiliigitus küllaltki detailne. Põhilised lähtekriteeriumid on järgmised: SEISUNDIT saab TEGEVUSEST eristada selle alusel, et SEISUND ei sisalda muutust, nt mingi objekti edasiliikumist (nt kirjutamisest kui TEGEvUSEST võib mõelda kui üksteisele järgnevatest faasidest, millest iga eelmisega kaasneb vahetulemus; muretsemises kui SEISUNDIS selliseid sisemisi faase aga eristada ei saa). TulemussündMUSE tegevusverbiga on põhjustamiskonstruktsioonis peaaegu alati seotud MõjuTATAV elus PATSIENT. PROTSESSIGA kaasneb tüüpiliselt millegi astmeline muutumine (nt ägenema). Siinses materjalis kuuluvad protsessiverbide alla enamasti verbid, mis väljendavad mingit kuuldeliselt tajutavat või füüsikalist sündmust ja millega kaasnevad põhjustamiskonstruktsioonis enamasti KOGEJA või elutu PATSIENT. Nii TEGEVUST kui ka PROTSESSI iseloomustab seega millegi muutumine, kuid TEGEVUSEGA on seotud elusolend, PROTSESS aga toimub millegi elutuga. Sooritus- ja saavutusverbe on TulEMUSSÜNDMUSENA materjalis vaid üksikuid ja need on seotud mingi tulemuseni jõudmisega. sooritus on tegevus ja see lõppeb mingi tulemusega, SAAVUTUs aga hetkeline tulemusele jõudmise sündmus (Vendler 1957).

Ühe osa verbide semantilise rolli määramine on ühemõtteline (nt kartma on SEIsUND, kuna ei näita muutumist), kuid mõne verbi tõlgendus võib olla esmapilgul kahetine. Näiteks võiks verb naerma eri tõlgenduste kohaselt väljendada nii PROTSESSI, SEISUNDIT kui ka TEGEVUST (siin füsioloogiline protsess). Materjali hulgas leidub mitmeid kahe või enama võimaliku tõlgendusega verbe: läikima, särama, 
ahastama, iiveldama, imestama, kihama, käituma, luksuma. Rohkem puudutab see protsessi- ja seisundiverbe, aga mõnel juhul ka tegevusverbe. Näitena võib tuua iiveldama, mida võiks määratleda kui inimese sEISUNDIT, aga sündmuse vaatepunktist ka kui PROTSESSI.

Põhimaterjali 458 kasutusjuhu hulgas esineb 16 erinevat konstruktsioonitüüpi. Tabelis 2 on järjestatud viie sagedama konstruktsioonitüübi kirjeldused, mille kasutusjuhte on kokku 411 (muid on kokku 47 ja nende osakaal 10,2\%). Robert Dixoni (2000) järgi iseloomustavad põhjustamiskonstruktsiooni sellised parameetrid nagu tahtlikkus ja põhjustaja osalemine sündmuses, ent kuna ajama-põhjustamiskonstruktsiooni nelja sagedama tüübi subjekti roll on Jõud, siis enamik parameetritest ongi määratletavad selle rolli järgi, nt ei saa Jõu rollis subjektiga konstruktsioonides rääkida MõjuTAJA tahtlikkusest või kontrollist.

Tabel 2. Viis sagedamat ajama-põhjustamiskonstruktsiooni tüüpi.

\begin{tabular}{|l|l|l|}
\hline Konstruktsioonitüüp & $\begin{array}{l}\text { Esinemissagedus } \\
\text { absoluutarvudes }\end{array}$ & $\begin{array}{l}\text { Esinemissagedus } \\
\text { protsentides }\end{array}$ \\
\hline JÕUD-KOGEJA-PROTSESS & 201 & $43,9 \%$ \\
\hline JOUUD-PATSIENT-TEGEVUS & 98 & $21,4 \%$ \\
\hline JÕUD-PATSIENT-PROTSESS & 49 & $10,7 \%$ \\
\hline JÕUD-KOGEJA-SEISUND & 43 & $9,4 \%$ \\
\hline AGENT-PATSIENT-TEGEVUS & 20 & $4,4 \%$ \\
\hline
\end{tabular}

Kõige sagedamas konstruktsioonitüübis $(43,9 \%)$ põhjustab Jõud KOGEJAGA toimuva PROTSESSI. Selle konstruktsioonitüübi sageduse muudab suureks see, et nutma- ja eriti naerma-verbi esineb väga palju. Muid TulEMUSSÜNDMUSE verbe esineb selles rühmas vaid üksikuid ja harva, nt deskriptiivverbid muigama, kõhistama, luksuma ja sügelema. Nimetatud füsioloogilised protsessid põhjustab jõud, seega ei ole põhjustamine tahtlik.

$\begin{array}{lllll}\text { VORM } & \text { subjekt } & \mathrm{V}_{1}^{\text {ajama }} & \text { objekt } & \mathrm{V}_{2}^{\text {ma }} \\ \text { TÄHENDUS } & \text { Jõud } & \text { põhjustama } & \text { KOGEJA } & \text { PROTSESs } \\ \text { NÄIDE } & \text { See mõte } & \text { ajas } & \text { mind } & \text { tegelikult naerma. }\end{array}$

Sageduselt järgmises konstruktsioonitüübis $(21,4 \%)$ põhjustab JõUD PATSIENDI TEGEVUSE. See rühm on eelmisest küll umbes kaks korda väiksem, kuid oma suure hulga erinevate TulEmussüNDMUSE verbide poolest produktiivsem. Selleski konstruktsioonitüübis ei põhjustata midagi tahtlikult. Asjaolud, millele mingi tegevusega reageeritakse, on näiteks kriis, mure, rahapuudus, kannatamatus, jalgpall ja ilus ilm.

$\begin{array}{lllll}\text { VORM } & \text { subjekt } & \mathrm{V}_{1}^{\text {ajama }} & \text { objekt } & \mathrm{V}_{2}^{\text {ma }} \\ \text { TÄHENDUS } & \text { Õud } & \text { põhjustama } & \text { PATSIENT } & \text { TEGEVUs } \\ \text { NÄIDE } & \text { Kriis } & \text { ajab } & \text { ettevõtjad } & \text { kunstnikelt abi otsima. }\end{array}$

PATSIENDIGA toimuva PROTSESSI põhjustab JÕUD 10,7\%-1 ajama-põhjustamiskonstruktsiooni juhtudest. 


$\begin{array}{lllll}\text { VORM } & \text { subjekt } & \mathrm{V}_{1}^{\text {ajama }} & \text { objekt } & \mathrm{V}_{2}^{\text {ma }} \\ \text { TÄHENDUS } & \text { JõUD } & \text { põhjustama } & \text { PATSIENT } & \text { PROTSESS } \\ \text { NÄIDE } & \text { Sool } & \text { ajab } & \text { lihtsalt vee } & \text { kiiremini keema. }\end{array}$

JÕUD põhjustab KOGEJALE mingi SEISUNDI 9,4\%-1 kasutusjuhtudest.

$\begin{array}{lllll}\text { VORM } & \text { subjekt } & \mathrm{V}_{1}^{\text {ajama }} & \text { objekt } & \mathrm{V}_{2}^{\text {ma }} \\ \text { TÄHENDUS } & \text { Jõud } & \text { põhjustama } & \text { KOGEJA } & \text { SEISUND } \\ \text { NÄIDE } & \text { Mustus ja rahvamassid } & \text { ajavad } & \text { mu } & \text { iiveldama. }\end{array}$

Sageduselt esimeses agentiivses konstruktsioonitüübis (4,4\%) põhjustab AGENT PATSIENDILE mingi TEgEvUSE. Siin on Mõjutaja kontrollija ja tahtlikult tegutseja, kuid tavaliselt ise põhjustatud tegevuses ei osale.

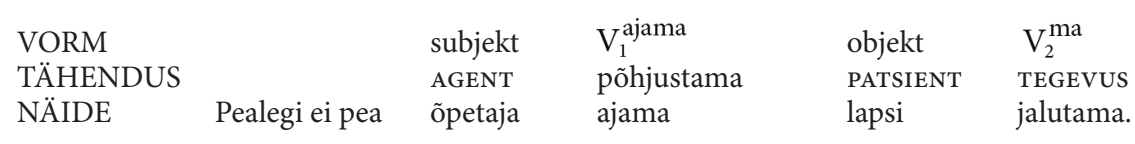

Sketch Engine'i kaudu otsiti ühendkorpusest ajama-verbi koosesinemisi erinevate sõnadega, et vaadata, kui kaugele jäävad sageduselt ajama-verbi esimesed grammatilised kasutused võrreldes teiste koosesinemistega. Kõige sagedam ühend on taga ajama (19 050 kasutusjuhtu). Sellele järgnevad sageduse järjekorras ühendid asju ajama, juttu ajama, asja ajama, välja ajama, ära ajama, läbi ajama, segi ajama ja närvi ajama. Grammatilistest kasutustest (infinitiivikonstruktsioonidest) esineb kõige sagedamini naerma ajama (6363 kasutusjuhtu), mis on sage ka kõikide teiste koosesinemiste seas. Ajama-verbi koosesinemisele verbiga naerma järgneb sageduselt hulk määrsõnu, nt püsti, peale, korda, üles, kokku ja segamini. Nendest vähem sagedad, kuid grammatilistest kasutustest sageduselt järgmised koosesinemised on nutma ajama (1613 kasutusjuhtu), keema ajama (1440), iiveldama ajama (1078) ja muigama ajama (716).

\subsection{Eksplitseerimata osalisega ajama-põhjustamiskonstruktsioon}

Koos ühendkorpusest lisaks võetud kasutusjuhtudega on analüüsitud kokku 1464 grammatilist ajama-põhjustamiskonstruktsiooni. Nendes on eksplitseerimata osalisega kasutuste osakaal 2/3: kõiki osalisi eksplitsiitselt väljendavaid juhte on 458 $(\sim 31,3 \%)$ ja eksplitseerimata osalisega juhte $1006(\sim 68,7 \%)$. Osalistest on kõige sagedamini jäetud nimetamata Mõjutatav. Enamasti on Mõjutatav kirjutaja ise ning järeldub kontekstist, nagu näidetes 35 ja 36.

(35) Esimene trenn ajas nutma. (naisteleht.ee)

(36) Autori jutt ajab muigama. (delfi.ee)

Osas juhtudest pole nimetatud ei Mõjutajat ega ka Mõjutatavat. Selliste kasutuste hulgas on kahte tüüpi lauseid: ühed, milles kumbki osalistest pole lauses nimetatud (näide 37), ja teised, kus põhilause küll viitab MõjutaJALE, aga ei nimeta seda 
otseselt (näited 38 ja 39). Näites 38 saab Mõjutajana tõlgendada leierdatud juttu, aga ka asjaolu, et see on nii leierdatud jutt. Samamoodi ajab näites 39 naerma tore teos, ehkki naeru põhjustab ka asjaolu, et teos on nii tore. Mõjutatav on ka näidetes 37-39 tõenäoliselt kirjutaja ise. Selliselt saab MõjutATAVAT tõlgendada blogide, foorumite vm oma arvamust sisaldavate internetilehekülgede tekstides.

(37) Ajas iiveldama ja oksendama. (hypnoteraapia.ee)

(38) See on nii leierdatud jutt, et ajab lausa iiveldama. (delfi.ee)

(39) Teos on nii tore, et ajab kuidagi südamerõõmuga naerma! (poogen.ee)

Lisaks jäetakse üks osaline (MõjUTAJA) grammatilistel põhjustel nimetamata käskivates ja umbisikulistes lausetes. Neid kasutusi pole aga palju ja põhiosa eksplitseerimata osalisega kasutustest moodustavad näidete 35-39 tüüpi laused.

\subsection{Ajama-põhjustamiskonstruktsiooni valdav mitteagentiivsus}

See, et ajama-põhjustamiskonstruktsioon on enamasti mitteagentiivne (Erelt, Metslang 2017: 234), ilmnes selgelt ka siinses uurimuses. Eksplitseerimata osalisega ajama-põhjustamiskonstruktsioonis on subjekti semantiline roll ligikaudu 90\%-1 kasutusjuhtudest Jõud ja vaid 10\%-l juhtudest AGENT. See erineb panema-põhjustamiskonstruktsioonist, kus Jõud ja AGENT esinevad subjekti semantilise rollina ligikaudu võrdse sagedusega (Tomson 2016: 46-47).

JõunA esinevad ajama-põhjustamiskonstruktsioonis paljud erinevad asjaolud, näiteks köha, pealkiri, (ta) nägu. On väljendutud ka pikemalt, nt see, mis ulmefännil südame kiiremalt põksuma paneb. Jõud võib olla väljendatud ka kõrvallausega, ehkki selline kasutus pole sage. Näited 40-42 esindavad erinevaid kõrvallausetüüpe.

(40) Siiamaani ajab muigama, kuidas n-ö suured juhid meie ümber unustavad nii vana ning lihtsa tõe - iga rahvas on oma juhti väärt ja iga juht on oma rahvast väärt. (director.ee)

(41) Ajab naerma, kui vaatan selle hinda ntx WMF köögiriistade seerias [---]. (naminami.ee)

(42) Kohapeal vaadates lihtsalt ajas naerma, kuna oli ainult kolm autot kes said sõiduga korralikult hakkama. (motors24.ee)

Võib kaaluda, kas Jõu suure osakaalu tingib naerma- ja nutma-verbi tunduvalt sagedam esinemine ajama-konstruktsioonis. Kui need materjalist välja arvata, siis esineb Jõud ligikaudu $88 \%$-s näidetest ja AGENT 12\%-s näidetest. See näitab, et ka muude verbidega konstruktsioonides on Jõu rollis MõjUTAJA osakaal agentiivsest MõjutATAVAST tunduvalt suurem ning seega ei mõjuta naerma- ja nutma-verbiga konstruktsioonide kõrge sagedus semantiliste rollide üldist protsentuaalset jagunemist.

See, et agentiivset ajama-põhjustamiskonstruktsiooni esineb harvem kui agentiivset panema-põhjustamiskonstruktsiooni, võib olla seotud verbi tähendusega sel 
viisil, et panema-verbi esmane leksikaalne asetamistähendus on palju sagedam kui ajama-verbi liigutamise ja lükkamise tähendus. Tõenäoliselt annaks seletuse ka see, kui vaadata kvantitatiivselt ajama-verbi ja panema-verbi leksikaalsete kasutuste ja sildkonstruktsioonide subjekti semantilist rolli (AGENT-JÕUD).

\section{Ajama-verbi tähendusrühmade suurus ja tähenduste seosed}

Eelmistes peatükkides kirjeldati ajama-verbi nelja leksikaalset tähendust, viit sildkonstruktsiooni ja grammatilist põhjustamiskonstruktsiooni. Nende tähendusrühmade suurused absoluutarvudes ja protsentides on esitatud tabelis 3 .

Tabelist 3 on näha, et ajama-põhjustamiskonstruktsiooni osakaal on XIX sajandil 7,2\%, XX sajandil 4,5\% ja alates 2000. aastast 7\%. Panema-põhjustamiskonstruktsiooni sagedused on järgmised: XIX sajandi I poolel 8,5\%, 1890.-1990. aastatel $15,4 \%$ ja 2000 . aastast alates $13,9 \%$ (Tomson 2016). Sellest võrdlusest on näha, et ajama-põhjustamiskonstruktsioon esineb kirjakeeles harvem kui panemapõhjustamiskonstruktsioon.

Kui tabelis 3 on iga tähendusrühma osakaal esitatud eraldi, siis joonisel 1 on leksikaalsed tähendused koondatud üheks rühmaks ja sildkonstruktsioonid teiseks rühmaks. Nende kõrval on grammatilise põhjustamistähenduse rühm.

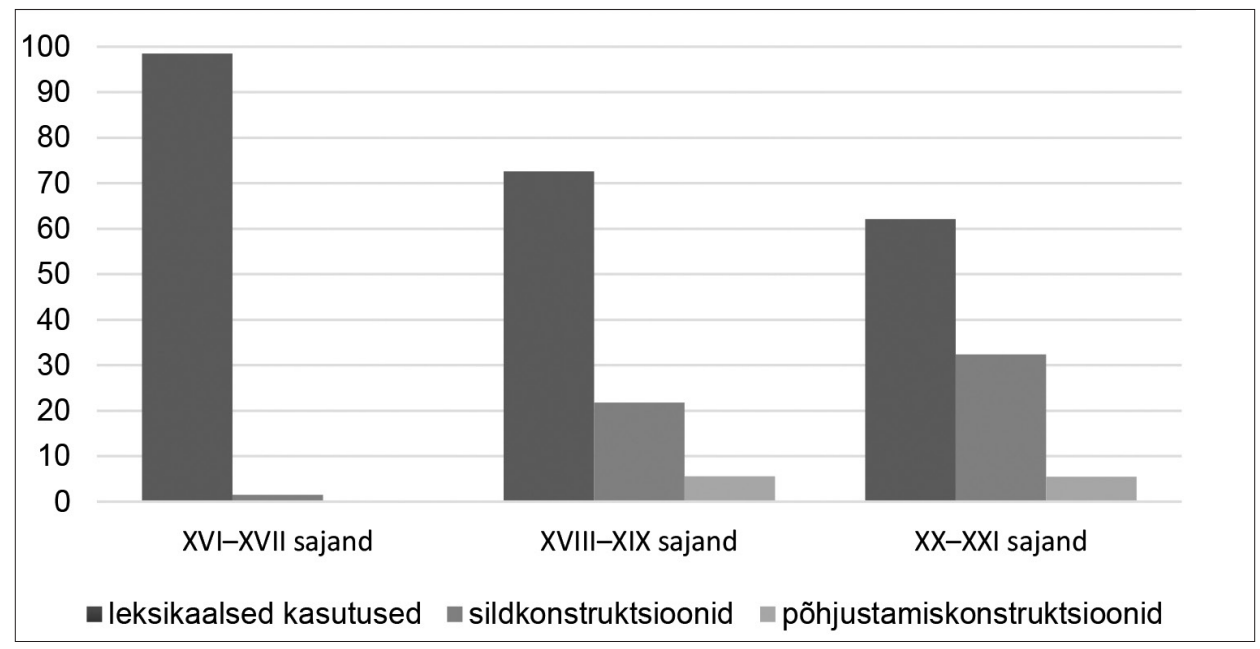

Joonis 1. Ajama-verbi kasutussagedus protsentides XVI-XXI sajandil.

Joonisel 1 on kujutatud ajama-verbi leksikaalsete tähenduste, sildkonstruktsioonide ja põhjustamiskonstruktsioonide sageduse muutust ajas. Põhjustamiskonstruktsioon tuli kirjakeeles kasutusele XIX sajandi algul ja pärast seda ei ole selle sagedus oluliselt muutunud. Jooniselt 1 on ka näha, kuidas leksikaalsete tähenduste osakaal on ajas pisut kahanenud ja sildkonstruktsioonide osakaal kasvanud. Seega on 


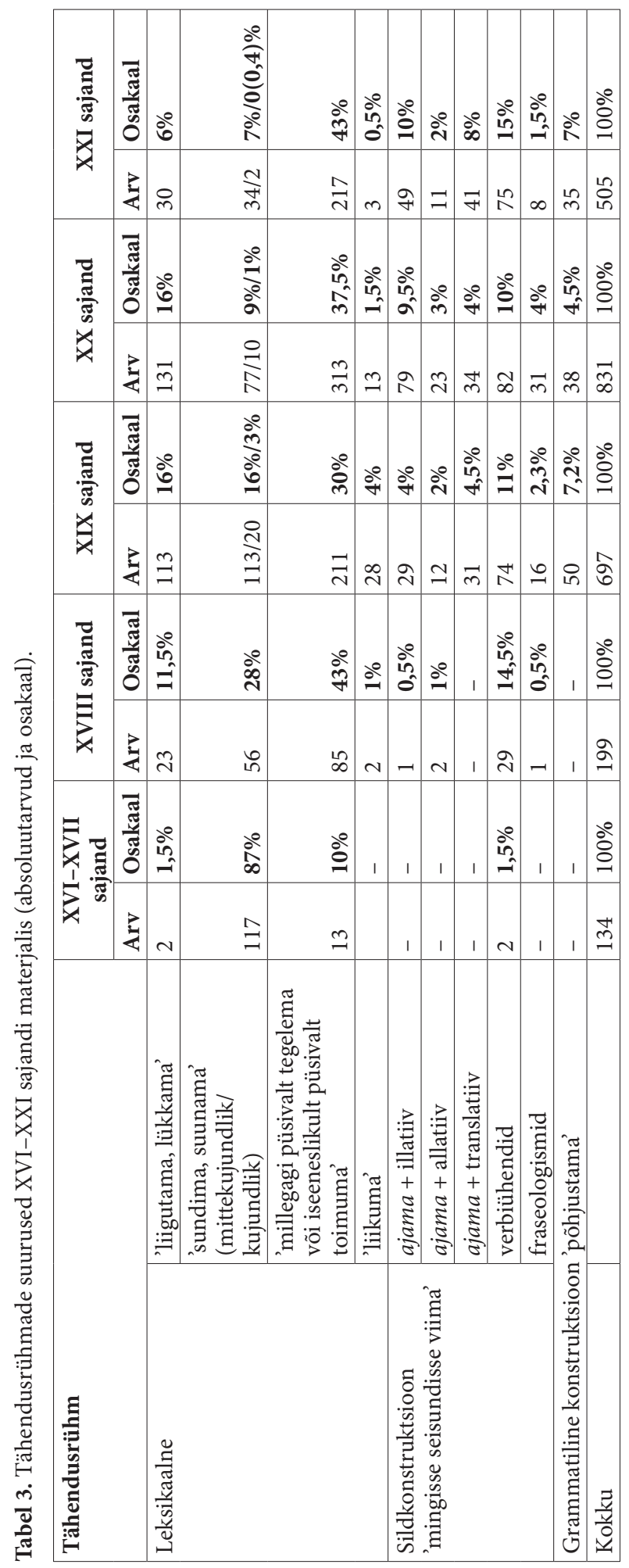


suurenenud ajama-verbi mingisse seisundisse viimise tähendust kandvate kasutuste osakaal. Sildkonstruktsioonide osakaalu kasv ajas osutab mingi keelendi kasutuse kujundlikumaks muutumisele ja grammatiseerumisele (vt nt Heine jt 1991).

Tabel 3 ja joonis 1 kujutasid ajama-verbi tähendusrühmade suurusi ja sageduse muutumist ajas, joonisel 2 on kujutatud ajama-verbi tähenduste vahelisi seoseid.

Joonise 2 keskel on kujutatud ajama-verbi kahte siinses uurimuses keskseks peetud tähendust: liigutamise ja lükkamise ning sundimise ja suunamise tähendust. Ülejäänud kaks leksikaalset tähendusrühma on 'liikuma' ja 'millegagi püsivalt tegelema või iseeneslikult püsivalt toimuma'. Füüsilist liigutamist ja lükkamist kui ajamaverbi esmast leksikaalset tähendust ei esine tänapäeva keeles rohkem kui teist, sundimise ja suunamise tähendust. Kannustamise tähenduses kasutused sundimise tähendusrühma sees on abstraktsemad selle poolest, et neis esineb subjektina jõUD (nt uudishimu), mitte AGENT.

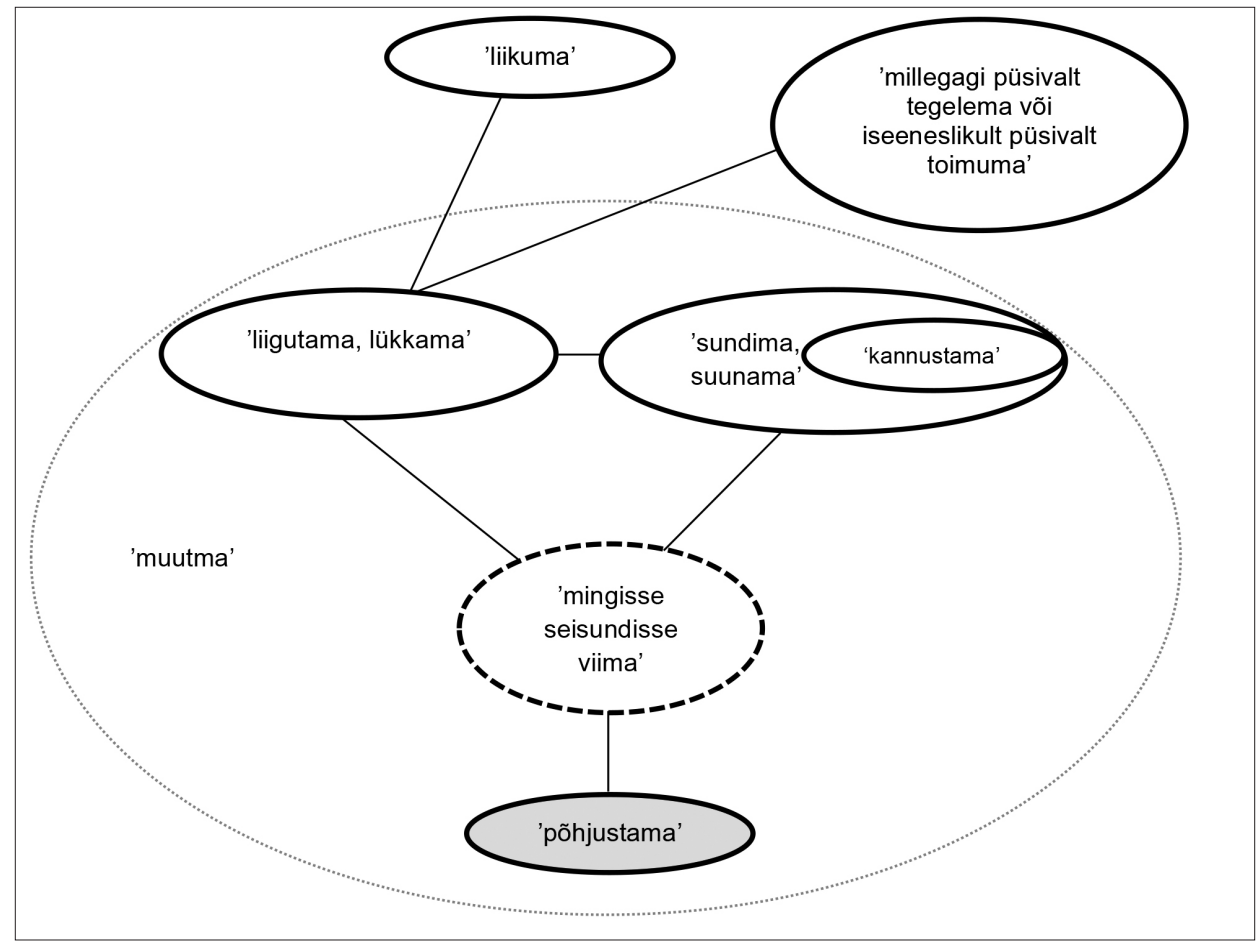

Joonis 2. Ajama-verbi tähendusseosed.

Ajama-verbi tähendusvõrgustikku iseloomustab see, et osa leksikaalsetest tähendustest (eriti 'sundima'), sildkonstruktsioonid ja grammatiline põhjustamistähendus on üksteisele tähenduslikult väga lähedal. Leksikaalsed tähendusrühmad on joonisel tähistatud pideva joonega, sildkonstruktsioonid punktiirjoonega ja grammatiline põhjustamistähendus pideva joone ja täitevärviga. Heleda punktiirjoonega on joonisel 2 ümbritsetud üldisem muutmise tähendus, mis ühendab tugevamalt seotud tähendusi - AGENDI või jõu rollis subjekt muudab kellegi või millegi 
asukohta, asendit või seisundit. Muutmine sobib eri tähendusi ühendavaks kategooriaks sellepärast, et hõlmab nii füüsilise objekti asukoha muutmist kui ka millegi seisundi või olukorra muutmist abstraktses mõttes. Nii saab muutmiskategooria kaudu selgitada ka ajama-verbi sildkonstruktsioonide (nt kuumaks ajama, pahaks ajama, korda ajama, meeleheitele ajama, laiali ajama) seost verbi leksikaalsete tähendustega, sest nii liigutamine, sundimine kui ka erinevatesse seisunditesse viimine seostuvad tähenduslikult muutmiskategooriaga. Sildkonstruktsioonid on joonisel tähistatud tumeda punktiirjoonega, et eristada neid leksikaalsetest tähendusrühmadest ja grammatilisest põhjustamistähendusest.

Ajama-põhjustamistähendusel on oluline seos kannustamise tähendusega, sest see on leksikaalsetest tähendustest ainus, mis samamoodi sisaldab jõu rollis subjekti. JõU rollis subjekt on ajama-põhjustamiskonstruktsioonis palju sagedam kui AGENDI rollis subjekt. Kannustamise tähenduses näiteid on materjalis siiski üsna vähe. Jõu rollis subjekt esineb ka paljudes ajama-verbi sildkonstruktsioonides, ehkki täpsemat märgendust sildkonstruktsiooni subjekti rolli kohta siinses analüüsis ei tehtud.

Ehkki Jõu rollis subjektiga põhjustamiskonstruktsiooni seos muude ajama-verbi tähendustega on suurema sageduse tõttu mõnevõrra rohkem tähelepanu all, on AGENDI rollis subjektiga põhjustamiskonstruktsiooni seos sundimise tähendusega ka selgelt nähtav ja oluline.

Ajama-verbi sildkonstruktsioonide võrdlemisi sage esinemus näitab, et see verb moodustab palju põhjustamiskonstruktsioonile lähedasi tarindeid ja grammatiseerub.

\section{Kokkuvõte}

Artikkel kirjeldab eesti keele tuumverbi ajama tähendusi ja nendevahelisi seoseid ning selgitab ajama-põhjustamiskonstruktsiooni kujunemist, olemust ja esinemist keelekasutuses. Materjal on kogutud XVI-XXI sajandi eesti kirjakeele korpustest.

Ajama-verbi leksikaalsed tähendused jaotati nelja rühma: 1) 'liigutama, lükkama' (nt (midagi) edasi ajama), 2) 'sundima, suunama' (nt (kedagi) välja ajama), 3) 'millegagi püsivalt tegelema või iseeneslikult püsivalt toimuma' (nt poliitikat ajama ja karva ajama) ja 4) 'liikuma' (nt (hobusega) ratsa ajama). Seos põhjustamistähendusega on liigutamisel ja lükkamisel ning sundimisel ja suunamisel, mille tähendusvälju ühendab muutmise tähendus. Leksikaalsetele kasutustele lisaks esinevad ajama-verbi kasutuste hulgas sildkonstruktsioonid, mis kannavad samuti muutmist väljendavat mingisse seisundisse viimise tähendust. Seisundid võivad olla füüsilised (nt krussi ajama) või abstraktsed (nt nurja ajama). Neid seisundeid väljendavad erinevad vormivahendid: ajama + translatiivis noomen (nt pahaks ajama), ajama + illatiivilähtene seisundivorm (nt raisku ajama), ajama + allatiivilähtene seisundivorm (nt liikvele ajama), verbiühendid (nt üles ajama 'äratama') või fraseoloogilised ühendid (nt kananahka ihule ajama).

Ajama-verbi ainuke grammatiline tähendus, põhjustamistähendus, ilmnes kirjalikes tekstides esmakordselt XIX sajandi algul. Tänapäeva eesti keeles esineb 
ajama-verb põhjustamiskonstruktsioonis umbes 7\%-l kõikidest selle verbi kasutusjuhtudest. Analüütilisse põhjustamiskonstruktsiooni (MõjUTAJA + ajama-verb + MõJUTATAV + TulEMUSSÜNDMUSE verb) sobitub ajama-verb niisiis ennekõike oma leksikaalse liigutamise ja lükkamise ning sundimise ja suunamise tähenduse kaudu, mis omakorda on tähenduslikuks aluseks põhjustamisega veel otsesemalt seostuvatele kellegi või millegi mingisse seisundisse viimise tähendust kandavatele sildkonstruktsioonidele.

Ajama-põhjustamiskonstruktsiooni uuriti 1464 kasutusjuhu põhjal, millest enamik on pärit korpusest etTenTen. 2/3 nendest kasutusjuhtudest on eksplitseerimata osalisega, st Mõjutaja, Mõjutatav või mõlemad osalised on jäetud lauses väljendamata (nt Esimene trenn ajas nutma). Täpsemalt uuriti selliseid ajama-põhjustamiskonstruktsiooni kasutusjuhte, milles kõik osalised on eksplitseeritud (458 kasutust). Iga kasutusjuhu puhul määrati Mõjutaja, Mõjutatava ja TulEmussündmuse verbi semantiline roll, millest selgus, et kõige sagedam ajama-põhjustamiskonstruktsiooni tüüp on JõUd-KOGEJA-PROTSESS (43,9\%), nt See mõte ajas mind tegelikult naerma. Enamasti ongi selle konstruktsioonitüübi TulemussüNDMUSE verb kas naerma või nutma. Nende verbide (eriti naerma-verbi) sage kasutus koos ajama-verbiga ilmnes ka Sketch Engine’ist. Sageduselt järgmine, kuid TulEMUSsüNDMUSE verbide poolest mitmekesisem ja produktiivsem konstruktsioonitüüp on JõUD-PATSIENT-TEGEVUS (21,4\%), nt Kriis ajab ettevõtjad kunstnikelt abi otsima. Jõud-PATSIENT-PROTSEsS tüüpi konstruktsioone esineb 10,7\% põhjustamiskonstruktsiooni kasutusjuhtudest, nt Sool ajab lihtsalt vee kiiremini keema, ja JõUD-KOGEJA-SEISUND tüüpi konstruktsioone 9,4\%, nt Isegi söetabletid ajavad neid öökima. Sageduselt esimene agentiivne konstruktsioonitüüp on AGENT-PATSIENT-TEgeVus $(4,4 \%)$, nt Pealegi ei pea ópetaja ajama lapsi jalutama. Ajama-põhjustamiskonstruktsioonis esinev subjekt oli vaadeldavas materjalis vaid umbes 10\%-l kasutusjuhtudest AGENT ja ülejäänud juhtudel JõUD.

Siinne analüüs ei tegelenud veel ajama- ja panema-põhjustamiskonstruktsiooni võrdlusega, kuid üldjoontes saab materjali põhjal väita, et ajama-põhjustamiskonstruktsiooni sagedus selle kõikidest kasutustest on tänapäeva kirjakeeles väiksem (umbes 7\%) kui panema-põhjustamiskonstruktsiooni sagedus (10-15\%) (Tomson 2018). Ajama-põhjustamiskonstruktsioonis on Jõu rollis Mõjutaja sagedam kui panema-põhjustamiskonstruktsioonis. Sildkonstruktsioonide põhiline sarnasus on nii ajama kui ka panema esinemine koos suunda väljendavate allatiivi- ja illatiivilähteste seisundivormidega. Artiklis esitati ajama-verbi tähendusrühmade ja sildkonstruktsioonide kirjeldused ning näidati tähendust ja vormi arvesse võttes, kuidas ajama-verb on nende kaudu sobitunud põhjustamiskonstruktsiooni. 


\section{ALLIKAVIITED}

Eesti keele ühendkorpus 2017. https://doi.org/10.15155/3-00-0000-0000-0000-071E7L

Eesti kirjakeele korpus. https://www.cl.ut.ee/korpused/kasutajaliides/index.php?lang=et

etTenTen korpus. http://www.keeleveeb.ee/dict/corpus/ettenten/

Vana kirjakeele korpus. http://vakk.ut.ee/

Sketch Engine. https://www.sketchengine.eu/

\section{KIRJANDUS}

Ahrens, Eduard 1853. Grammatik der Ehstnischen Sprache Revalschen Dialektes. Zweiter Theil: Satzlehre. Reval: Kluge und Ström.

Dixon, Robert M. W. 2000. A typology of causatives: form, syntax and meaning. - Changing Valency: Case Studies in Transitivity. Toim R. M. W. Dixon, Alexandra Y. Aikhenvald. Cambridge: Cambridge University Press, lk 29-83.

EES = Eesti etümoloogia sõnaraamat. Peatoim Iris Metsmägi. Toim I. Metsmägi, Meeli Sedrik, Sven-Erik Soosaar. Tallinn: Eesti Keele Sihtasutus, Eesti Keele Instituut, 2012.

EKSS = Eesti keele seletav sõnaraamat. http://www.eki.ee/dict/ekss/ (6. V 2019).

ESS = Eesti-soome sõnaraamat. Veebisõnaraamat. Tallinn-Helsinki: Eesti Keele Instituut, Kotimaisten kielten keskus, 2019. http://www.eki.ee/dict/fie/ (28. VI 2019).

Erelt, Mati; Metslang, Helle (toim) 2017. Eesti keele süntaks. (Eesti keele varamu 3.) Tartu: Tartu Ülikooli Kirjastus.

Ernits, Enn 2008. Läänemeresoome käändesüsteemidest Mihkel Veske kirjatööde valgusel. Emakeele Seltsi aastaraamat 53 (2007). Tallinn: Teaduste Akadeemia Kirjastus, lk 23-37.

Goldberg, Adele E. 1995. Constructions: A Construction Grammar Approach to Argument Structure. Chicago: The University of Chicago Press.

Heine, Bernd; Claudi, Ulrike; Hünnemeyer, Friederike 1991. Grammaticalization. A Conceptual Framework. Chicago-London: The University of Chicago Press.

Hopper, Paul J.; Traugott, Elizabeth Closs 1993. Grammaticalization. (Cambridge Textbooks in Linguistics.) Cambridge: Cambridge University Press.

Häkkinen, Kaisa 2005. Nykysuomen etymologinen sanakirja. 3. tr. Juva: WS Bookwell Oy.

Kasik, Reet 1999. Ajab segadusse: eesti ja soome keele leksikaalsetest erinevustest. - Lähivertailuja, nr 10. (Folia fennistica \& linguistica 23.) Tampere: Tampereen yliopiston suomen kielen ja yleisin kielitieteen laitos, lk 29-38.

Kasik, Reet 2001. Analytic causatives in Estonian. - Estonian: Typological Studies V. (Tartu Ülikooli eesti keele õppetooli toimetised 18.) Toim Mati Erelt. Tartu: Tartu Ülikooli Kirjastus, lk 77-122.

Kasik, Reet 2015. Sõnamoodustus. (Eesti keele varamu 1.) Tartu Ülikool: Tartu Ülikooli Kirjastus.

Lindström, Liina 2012. Tundekausatiivikonstruktsioon eesti moodi. - Keel ja Kirjandus, nr $1,1 \mathrm{k} 30-47$.

Nolan, Brian; Rawoens, Gudrun; Diedrichsen, Elke (toim) 2015. Causation, Permission, and Transfer Argument realisation in get, take, give and let verbs. (Studies in Language Companion Series 167.) Amsterdam-Philadelphia: John Benjamins, lk 107-127. 
Pakerys, Jurgis 2017. Baltic context of some Estonian periphrastic causative constructions. ESUKA-JEFUL, kd 8, nr 1, lk 179-195.

RKS $=$ Kuusalu rannakeele sõnaraamat. Veebiversioon. http://www.eki.ee/dict/kuusalu/ (27. V 2020).

Saareste, Andrus 1958-1963. Eesti keele mõisteline sõnaraamat. Kd I-IV. Stockholm: Vaba Eesti.

Stefanowitsch, Anatol 2001. Constructing Causation: A Construction Grammar Approach to Analytic Causatives. Doctoral dissertation. Houston, Texas: Rice University.

Tomson, Kairit 2016. Panema-verbi polüseemia ja kasutus grammatilistes konstruktsioonides. Magistritöö. Tartu: Tartu Ülikool. http://hdl.handle.net/10062/51758

Tomson, Kairit 2018. Panema-verb ja selle grammatilised kasutused. - Keel ja Kirjandus, nr 3, lk 199-216.

Tragel, llona 2003. Eesti keele tuumverbid. (Dissertationes linguisticae Universitatis Tartuensis 3.) Tartu: Tartu Ülikooli Kirjastus.

Tragel, llona; Taremaa, Piia 2019. Eesti keele verbide semantilisest liigitamisest. - Keel ja Kirjandus, nr 3, lk 207-222.

Vendler, Zeno 1957. Verbs and times. - The Philosophical Review, kd 66, nr 2, lk 143-160.

Wiedemann, Ferdinand Johann 1875. Grammatik der ehstnischen Sprache, zunächst wie sie in Mittelehstland gesprochen wird, mit Berücksichtigung der anderen Dialekte. Présenté le 13 Novembre 1873. St.-Pétersbourg.

Wiedemann, Ferdinand Johann 1923 [1869]. Eesti-saksa sõnaraamat. Kolmas, muutmata trükk teisest, Jakob Hurda redigeeritud väljaandest. Tartu: Eesti Kirjanduse Seltsi Kirjastus.

Kairit Tomson (snd 1986), MA, Tartu Ülikooli eesti ja soome-ugri keeleteaduse doktoriõpe (Jakobi 2, 50090 Tartu), kairit.tomson@ut.ee

\section{MAKE-causative on the example of Estonian ajama}

Keywords: polysemy, grammaticalization, causative construction, verb ajama, literary language, Estonian

This paper examines the polysemy of the Estonian core verb ajama ('to move something; to force someone') and focuses on the development and use of the ajama-(lit. drive)-causative (MAKE-causative; henceforth ajama-causative). The analysis draws on corpus data consisting of written Estonian texts from the $16^{\text {th }}$ century until the present day. As many as 2,366 cases of ajama were analysed in order to decide over the meaning groups of the verb and the relations between its meanings.

The lexical meanings of the verb ajama are 'to move or push something,' to force or direct someone', 'to deal with something (continually)' and 'to move'. A remarkable number of ajama cases appear in the constructions that have the meaning 'to put something or someone into a physical or abstract state. These constructions are 
considered as bridging constructions, as they have both lexical and grammatical meaning. The percentage of bridging constructions is rising in Estonian, nowadays accounting for around 32 per cent of all the cases of the verb ajama. The verb ajama expresses causal meaning in a causative construction (causer + ajama + causee + $\left.\mathrm{V}_{\text {ma-inf }}\right)$.

In addition, 1,341 cases of the ajama-causative were extracted from the Estonian National Corpus. It turned out that $2 / 3$ of the cases of the ajama-causative do not explicitly express either the causer or the causee. The cases of the ajama-causative expressing both causer and causee were analysed in detail. The 458 such cases can be divided into 16 construction types. The most frequent type of the ajama-causative is FORCE-EXPERIENCER-PROCESS (about half of the cases). In this type, the verb of the result situation is mostly naerma 'to laugh' or nutma 'to cry'. The next frequent type is FORCE-PATIENT-ACTION (around 20\%), in which the result situation can be expressed by various verbs and which is therefore a more productive type than FORCE-EXPERIENCER-PROCESS. The next types that follow in frequency are FORCEPATIENT-PROCESS (around 10\%) and FORCE-EXPERIENCER-STATE (around 10\%). The fifth most frequent type, AGENT-EXPERIENCER-STATE (around 5\%), is the first containing AGENT as causer. The analysis shows that AGENT as causer is rare in the ajama-causative, appearing only in $10 \%$ of all ajama-causative cases.

Kairit Tomson (b. 1986), MA, University of Tartu, Estonian and Finno-Ugric Linguistics,

PhD student (Jakobi 2, 51005 Tartu), kairit.tomson@ut.ee 